University for Business and Technology in Kosovo

UBT Knowledge Center

UBT International Conference

2014 UBT International Conference

Nov 7th, 2:45 PM - 3:00 PM

\title{
Valuing companies listed on the Macedonian Stock Exchange on the basis of the profitability of the investment
}

\author{
Bukurie Imeri Jusufi \\ University for Business and Technology, bukurie.jusufi@ubt-uni.net
}

Azir Jusufi

University for Business and Technology, azir.jusufi@ubt-uni.net

Follow this and additional works at: https://knowledgecenter.ubt-uni.net/conference

Part of the Business Commons

\section{Recommended Citation}

Jusufi, Bukurie Imeri and Jusufi, Azir, "Valuing companies listed on the Macedonian Stock Exchange on the basis of the profitability of the investment" (2014). UBT International Conference. 35.

https://knowledgecenter.ubt-uni.net/conference/2014/all-events/35

This Event is brought to you for free and open access by the Publication and Journals at UBT Knowledge Center. It has been accepted for inclusion in UBT International Conference by an authorized administrator of UBT Knowledge Center. For more information, please contact knowledge.center@ubt-uni.net. 


\title{
Valuing companies listed on the Macedonian Stock Exchange on the basis of the profitability of the investment
}

\author{
Bukurie Imeri Jusufi ${ }^{1}$, Azir Jusufi ${ }^{2}$ \\ 1,2 University for Businnes and Technology, Prishtina, KOSOVO \\ ㄹukurie.jusufi@ubt-uni.net; ${ }^{2}$ azir.jusufi@ubt-uni.net
}

\begin{abstract}
The investment strategy to be used by an investor will depend on the form of the price efficiency of the capital market. The reaching of an appropriate business decision about the investment of available financial means is not always easy. Therefore, it is necessary to perform a good analysis of the profitability and the logicality of the investment of available finances. The analysis based on the financial reports data which are publicly available enables the determining of certain indicators which can be used to value the companies, on the basis of which a rational decision can be reached in the case there is desire to invest in those companies. Except in real investments, nowadays investors more and more prefer to invest in securities, shares or bonds. Investments in the form of shares are more attractive for those investors who take higher risk, but at the same time expect a higher revenue.
\end{abstract}

Keywords: securities, capital market, financial instruments, market value, book value, stock exchange, intrinsic value, relative indicators, etc.

\section{Introduction}

The companies which are part of the stock exchange market, i.e. which are listed on the stock exchange publish their financial reports publicly in order to increase the transparency and so that all investors could have access to the information. From the presented information, they take sufficient data to calculate certain indicators or to make an analysis of the company in terms of its operation. The investors, as we previously mentioned, are interested in their results which are often determined by the prices of their shares. They also take into consideration the subjective approach for determining the value of the company and the results of its operation in order to reach a business decision which is the most profitable for them.

In this respect, certain research has been conducted in terms of the valuing of the companies listed on the Macedonian Stock Exchange, from different aspects, using different indicators, in order to enable the current and potential investors to have an advantageous choice when investing.

The valuation models based on assets, dividends, monetary flows and revenues are identical in the perfect conditions. However, in the reality, the results received by applying different valuation models differ. The data used in the valuation models in a certain environment represent an estimation of the expected future revenue, which should be adjusted to make a forecast about the future.

There are numerous models for valuing the share capital: ${ }^{1}$ a two-stage dividend discount model, a model of dividend discount with revenues multiplied by the final value, a three-stage dividend discount model, a free cash flow for the company, a free cash flow for the share capital, market value. Some of these models, due to the lack of official data cannoot be applied for the companies which are listed on the stock market, for example the impossibility to calculate the $\beta$ coefficient for the shares issued by the companies listed on the stock market. The statistical method enables the calculation of this coefficient on the basis of the following formula:

$$
\beta_{i}=\frac{\operatorname{cov}_{i, m}}{\sigma_{m}^{2}}
$$

\footnotetext{
${ }^{1}$ Zvi Bodie, Alex Kane, Alan Marcus, Investments - (translation from English), Tabernakul, 2010, p.
} 627. 
Where: $\operatorname{cov}_{i, m}$ - is a covariance of the portfolio

$$
\sigma_{m}{ }^{2} \text { - is a variance of the market }
$$

\subsection{Valuing the company share capital on the basis of revenue made}

This manner of share capital valuation is the easiest way to conduct valuation since it has a wide application in practice; the revenue accrued with the regular operation is taken as a basis for valuation. However, one needs to take into consideration certain conditions, i.e. circumstances in which the company is in since as the valuation is based on the revenue; if the companies are new or if the companies operate under the influence of certain circumstances depending on their branch of operation or during the time period analyzed the company has been operating with losses over several years, it means that without conducting a detailed analysis of what is the reason for the loss, such companies should not be ignored as possible companies for good investments.

The valuation of companies on the basis of revenues is conducted by applying the indicator which measures the ratio between the market capitalization and the revenues. A comparison of the current market value of the company with the revenues it made is being done. The market capitalization can be found by multiplying the current stock market price of the shares with the number of shares sold. This indicator is changeable since the shares are sold everyday. The values of the companies listed on the stock market are represented in Table 1. using the previously mentioned indicato

Table 1. Indicator market capitalization / revenues for the companies participating in the MBI 10 for the period 2008-2012

\begin{tabular}{|c|c|c|c|c|c|}
\hline Alkaloid $\mathbf{A D}^{2}$ & 20.02 & 14.50 & 18.57 & 19.59 & 69.63 \\
\hline Beton AD & 5.20 & 7.04 & 19.83 & 11.14 & 8.01 \\
\hline GD Granit AD & 5.34 & 4.67 & 5.31 & 6.00 & 4.03 \\
\hline ZK Pelagonija AD & 2.57 & 2.67 & 26.45 & 28.5 & 20.80 \\
\hline Komercijalna banka AD & 16.37 & 7.33 & 12.96 & 8.92 & 90.35 \\
\hline Makpetrol & 0.95 & 2.66 & 4.44 & 5.46 & 13.75 \\
\hline Makstil & 28.9 & 12.99 & 56.54 & 3.28 & 3.02 \\
\hline Replek AD & 85.41 & 31.76 & 32.34 & 11.54 & 8.04 \\
\hline Stopanska Banka AD Bitola & 16.46 & 9.41 & 33.81 & 18.6 & 15.12 \\
\hline Toplifikacija AD & 6.12 & 5.82 & 13.14 & 19.37 & 16.34 \\
\hline
\end{tabular}

Source: Financial reports of companies participating in the MBI 10 for the period $2008-2012$ and own calculations

The indicator market capitalization / revenues gives the opportunity to value the company through the sale of shares, i.e. the extent to which the market values each denar of sales of a specific company. Each indicator obtained should be taken into consideration regardless whether it is less than 1, or it is 100 . Knowing that there is no company which in its capital structure does not have debts regardless whether they are long-term or mid-term debts (i.e. the structure of the capital should be taken into consideration

\footnotetext{
2 Translator's comment: AD stands for Joint-Stock Company
} 
since the higher the degree of indebtedness, the higher the financial risk is). The indicator analysis should not be made isolated from the other indicators for the operation. Although this indicator is below 1 , it could be attractive if there are no debts for the settlement of which new shares would need to be issued, thus increasing the market capitalization and at the same time this indicator as well. The indicator revenue / capitalization is the highest for Alkaloid AD Skopje in 2008 when it was $69.63 \%$ and in Replek AD Skopje in 2012, when it was $85.41 \%$, i.e. the shares valued the highest were from the pharmaceutical industry, whereas the lowest is the indicator of Makpetrol AD Skopje, which is $0.95 \%$ in 2012 and ZK Pelagonija, which is $2.57 \%$ i.e. the branch of transport and the food industry. However, besides the advantage of this indicator, one should have in mind the negative side as well, since this indicator is also below 1 for companies on the verge of bankruptcy; in the concrete case, since they were calculated for companies which are top-performing in the Republic of Macedonia, we do not have such calculated indicator for companies.

\subsection{Valuing the company share capital on the basis of the profit made}

The goal of the operation of each company throughout the year is the making of profit, i.e. a positive financial result, but the expectations are not always fulfilled as a result of the influence of different circumstances.

On the basis of the net revenue, two indicators are calculated: earnings per share and the ratio of the share price and earnings per share.

EPS - earnings per share represents one of the most important indicators of the company's operation, which is also regulated with an international book-keeping standard - MSS 33. This indicator is obtained when the net earnings are related with the weighted average number of ordinary shares in the appropriate period, i.e.: ${ }^{3}$

Earnings per share $=\frac{\text { net earnings }}{\text { weighted average number of ordinary shares }}$

Table 2. EPS of the shares of companies participating in MBI 10 for the period 2008-2012

\begin{tabular}{llllll}
\hline Alkaloid AD & 407.82 & 430.54 & 401.26 & 390.18 & 350.57 \\
Beton AD & 818.54 & 648.51 & 567.72 & 341.43 & 367.49 \\
GD Granit AD & 94.82 & 129.42 & 95.35 & 105.83 & 130.40 \\
ZK Pelagonija & 611.47 & 999.01 & -165.14 & -548.02 & 856.16 \\
$\begin{array}{l}\text { Komercijalna } \\
\text { banka AD }\end{array}$ & 246.63 & 476.44 & 628.36 & 538.05 & 690.32 \\
$\begin{array}{l}\text { Makpetrol AD } \\
\text { Makstil }\end{array}$ & -599.66 & -26.77 & -2.037 .51 & -2.551 .49 & 2.326 .74 \\
Replek AD & -0.66 & -4.99 & 2.92 & 0.11 & 4.67 \\
& 6146.41 & 5.606 .29 & 2.980 .40 & 5.625 .6 & 9.273 .84 \\
\hline
\end{tabular}

${ }^{3}$ Gerald White, Ashwinpaul Sondhi, Dov Fried: The Analysis and Use of Financial Statements (translation from English), Securities and Exchange Commission of the Republic of Macedonia, Skopje, 2003, p. 233. 
$3^{\text {rd }}$ International Conference on Business, Technology and Innovation

\begin{tabular}{llllll}
\hline $\begin{array}{l}\text { Stopanska } \\
\text { BankaAD } \\
\text { Bitola }\end{array}$ & -374.85 & -1.218 .74 & 39.99 & 211.39 & 473.85 \\
$\begin{array}{l}\text { Toplifikacija } \\
\text { AD }\end{array}$ & 85.41 & 19.71 & 277.07 & 66.25 & 11.55 \\
\hline
\end{tabular}

Source: Financial reports of companies participating in MBI 10 for the period 2008-2012

On the basis of this method of share capital evaluation, too, the shares of Replek AD made the highest earnings, whereas the lowest earnings were made by the shares of Makpetrol AD.

Nevertheless, we know that the value of the capital increases with the increase of the price of shares on the market, and not based on the expected earnings. On the basis of the EPS, we can calculate the next indicator which could give us more information about the operation of the companies which is very important for the investors - the ratio of market price per share and earnings, i.e.: ${ }^{4}$

$$
\text { Indicator - price and earnings }=\frac{\text { Market price per share }}{\text { Earnings per share }}
$$

The obtained indicator shows the market rating of the company, i.e. how much the market price per share is greater than the earnings; in that case there is greater demand for the shares, and at the same time this indicates that the company is in the stage of further development, i.e. the shares of Replek may be called growth shares, whereas the shares for which the indicator is low, specifically the shares of Makpetrol, Stopanska Banka and Makstil can be called value shares, i.e. the expectations are that in the future the prices of these shares will grow; the low indicators are not always a signal that the prices of the shares will not grow.

Table 3. Indicator price / earnings of companies participating in MBI 10 for the period 2008-2012

\begin{tabular}{llllll}
\hline & & & & & \\
\hline Alkaloid AD & 10.08 & 9.22 & 9.75 & 12.15 & 8.53 \\
Beton AD & 3.67 & 7.71 & 11.63 & 35.77 & 24.48 \\
GD Granit AD & 4.02 & 3.63 & 5.56 & 7.03 & 4.52 \\
ZK Pelagonija AD & 9.78 & 2.16 & $/$ & $/$ & 2.80 \\
Komercijalna banka AD & 9.79 & 5.10 & 4.56 & 5.2 & 5.2 \\
Makpetrol & $/$ & $/$ & $/$ & $/$ & 13.75 \\
Makstil & $/$ & $/$ & 56.54 & 1.856 .8 & 21.63 \\
& & & & 5 & \\
\hline
\end{tabular}

\footnotetext{
${ }^{4}$ Gerald White, referenced work p. 234 and Pamela Peterson, referenced work, p. 121
} 


\begin{tabular}{|c|c|c|c|c|c|c|}
\hline Replek AD & 6.83 & & 6.60 & 12.58 & 7.91 & 5.07 \\
\hline Stopanska Banka AD Bitola & & / & I & 70.9 & 17.26 & 5.82 \\
\hline Toplifikacija AD & 17.91 & & 154.95 & 209.91 & 70.94 & 248.85 \\
\hline
\end{tabular}

Source: Financial reports of the companies for the period 2008-2012

The companies which have a high indicator allocate a little for profits, whereas the companies which make higher profits and pay out a dividend have a low indicator. A high value of this indicator points to the fact that a high growth of profits is expected. The Makstil AD Skopje company has a high indicator in 2009 - it totals $1,865.85$ which means that the investors want to pay $1,865.85$ denars for each denar of profit, i.e. that the price of the share is 1,865.85 times higher than its earning potential, compared with the other companies listed on the Macedonian Stock Exchange. Nevertheless, one should act and review this indicator carefully and together with the other indicators. This indicator is higher in 2010 for the Toplifikacija AD Skopje company - 209.91 denars.

The price and earnings growth indicator also takes into consideration the planned rate of growth of the profit per share for the forthcoming period. However, the expectations regarding the growth of the shares can not always be as predicted since they depend on other factors as well: the environment in which the company operates or the cycle of development due to which the planned growth cannot be accomplished. It is calculated in the following manner: ${ }^{5}$

$$
\text { Price and earnings growth indicator }=\frac{\text { Price and earnings indicator }}{\text { Planned growth rate of theearnings per share }}
$$

If the indicator has a value greater than 1 , then it indicates that the issued shares have been overpriced or that a slight growth of the profit per share is foreseen, and the price of the shares remains stable, or it is expected for the future growth of the earnings per share to be greater than the current one. If the indicator is lower than 1, it means that the shares have been underprized or it is not expected for the future growth of the earnings per share on the market to be greater than the current one. The possibility for the perspective growth of the company can be observed using this indicator. Nevertheless, it is still a little problematic, since this is about planned growth, for which there is uncertainty regarding its accomplishment in the period for which it has been predicted. If we assume that there will be a planned growth of $3 \%$ for all the shares which are part of MBI 10, in the case the companies operate in the same circumstances and have the same level of risk like in the previous calculations, then these indicators will be as follows (table 4.).

Table 4. Planned 3\% profit growth for the period 2008-2012

\begin{tabular}{llllll}
\hline & & & & & \\
\hline Alkaloid AD & 336 & 307.3 & 325 & 405 & 284.3 \\
Beton AD & 122.33 & 257 & 387.66 & 1192.3 & 816 \\
GD Granit AD & 134 & 112 & 185 & 234 & 150.7 \\
\hline
\end{tabular}

${ }^{5}$ Gerald White, referenced work p. 233 
$3^{\text {rd }}$ International Conference on Business, Technology and Innovation

\begin{tabular}{|c|c|c|c|c|c|}
\hline ZK Pelagonija AD & 326 & 72 & l & l & 93.3 \\
\hline Komercijalna banka AD & 326 & 496.3 & 152 & 173 & 346.7 \\
\hline Makpetrol & l & l & 1 & 1 & 458.3 \\
\hline Makstil & l & l & 1884.7 & 61895 & 721 \\
\hline Replek AD & 227.7 & 220 & 419 & 263.7 & 169 \\
\hline $\begin{array}{l}\text { Stopanska } \\
\text { Bitola }\end{array}$ & & $1 /$ & 2363.3 & 575 & 769.3 \\
\hline Toplifikacija AD & 597 & 5165 & 6997 & 2364.67 & 8295 \\
\hline
\end{tabular}

Source: Own calculations

This indicator is higher for the shares of Toplifikacija AD, especially in 2008 and it is 8,295 , whereas the indicator of ZK Pelagonija is the lowest. If the first five companies with the highest indicator are grouped by branch of industry, they remain to be representatives of the pharmaceutical, construction and energy industries (table 4.).

\section{Valuing the company share capital on the basis of the cash flow}

Cash flow is taken into consideration when valuing companies, since it is the cash which moves through the company during a certain period after the payment or the settling of the fixed charges from the interest rates, rent and dividend of the preference shares. Usually, it is defined as earnings before interest, taxes, depreciation and amortization - EBITDA ${ }^{6}$. It focuses on the operational activities (the financial and investment activities are not taken into account), it represents an indicator of the financial result because of which it can be used as a valuable element when valuing companies. It represents an important indicator for investors since it points to the difference between the business revenues and the business expenditures, not including amortization. It is applied when one wants to show the ability of the company to settle obligations, i.e. financial expenditures and tax on profit. The investors may express this indicator as a percentage of the sale in a way that the higher this indicator as a percentage is, the greater the profitability is. It can be used for all companies, thus enabling their easier comparison.

Table 5. EBITDA of some companies which are listed on the stock market for the period 20082012

\begin{tabular}{|c|c|c|c|c|c|}
\hline Alkaloid AD & $11.19 \%$ & $11.65 \%$ & $10.91 \%$ & $10.92 \%$ & $10.65 \%$ \\
\hline Beton AD & $13.07 \%$ & l & I & I & I \\
\hline GD Granit AD & I & I & I & I & I \\
\hline ZK Pelagonija AD & l & l & I & I & l \\
\hline $\begin{array}{l}\text { Komercijalna } \\
\text { banka AD }\end{array}$ & $13.07 \%$ & $25.98 \%$ & $34.11 \%$ & $26.85 \%$ & / \\
\hline
\end{tabular}

Source: Financial reports of the company for the period 2008-2012

\footnotetext{
${ }^{6}$ Gerald White, referenced work p. 233
} 
The indicator earnings before interest and taxes is useful for the earning potential of the company, and as a relative number of the percentage of the sale, it can be compared with other companies in terms of their valuation. Although Table 5. only lists some of the companies which are listed on the stock market, it can be observed that Komercijalna Banka AD has the highest profits compared with the other companies, but these companies are not from the same branch of operation.

\section{Valuing the company share capital on the basis of capital}

If the valuing of the company is done on the basis of the capital, the following indicators can be taken into consideration: net turnover funds in relation with the market capitalization, price and book value ratio, and as a third indicator - return on capital employed.

The net turnover funds represent one of the important indicators - they are the difference between the current funds and the current liabilities. They indicate which part of the current funds is financed from long-term sources. A second way to calculate them is to subtract the current funds from the long-term capital (own and others'). Actually, the company which disposes of net turnover funds in its balance sheet has an important quality in its financing, since on the basis of the turnover funds and the current liabilities, one can determine the liquidity indicator. The net turnover funds of the company represent sources to use in the current operation and therefore it is said that if some company is bought at a price close to the net turnover funds, in reality, a denar of property is bought for a denar of market share price, which would be a good thing. Because of it, the monitoring of the size of the net turnover funds represents a good basis or indicator for the investors in terms of the valuing of the company which they need to invest in.

The book value is also an important measurement to value companies. It is found in the balance sheet, and in principle it equals the difference between the total active capital and the total liabilities. In order to value a company, this measurement should be brought down to the book value per share which can be obtained by dividing the book value with the number of issued shares. The indicator which is used for the valuation in fact represents the ratio between the market price and the book price per share, i.e.:

$$
\frac{\text { Market price per share }}{\text { Book price per share }}=\frac{P}{B}
$$

This indicator indicates how much the market pays for the book value of the company. The lower this indicator is, the better it is for the company.

Table 6. Indicator market / book value per share of the companies listed in the Macedonian Stock Exchange for the period 2008-2012

\begin{tabular}{lccccc}
\hline & & & & & \\
\hline Alkaloid AD & 0.82 & 0.82 & 0.85 & 1.08 & 0.74 \\
Beton AD & 0.08 & 0.14 & 0.19 & 0.36 & 0.27 \\
GD Granit AD & 0.28 & 0.37 & 0.49 & 0.74 & 0.63 \\
\hline
\end{tabular}

${ }^{7}$ Gerald White, referenced work p. 218, Steven Bragg, referenced work p. 382, Pamela Peterson, referenced work p. 121. 
$3^{\text {rd }}$ International Conference on Business, Technology and Innovation

\begin{tabular}{llllll}
\hline \multicolumn{1}{c}{ ZK Pelagonija AD } & 0.84 & 0.30 & 0.33 & 0.46 & 0.30 \\
$\quad$ Komercijalna banka AD & 0.57 & 0.58 & 0.82 & 0.8 & 0.88 \\
Makpetrol & 0.36 & 0.44 & 0.7 & 1.03 & 0.81 \\
Makstil & 1.37 & 1.52 & 2.21 & 2.87 & 1.41 \\
Replek AD & 0.78 & 0.72 & 0.76 & 0.89 & 0.93 \\
Stopanska Banka AD Bitola & 0.50 & 0.61 & 0.67 & 0.83 & 0.62 \\
Toplifikacija AD & 0.41 & 0.61 & 0.9 & 1.34 & 0.82 \\
\hline
\end{tabular}

Source: Financial reports for the companies from which the MBI 10 index is calculated for the period 2008-2012

Companies with lower coefficient compared with the average coefficient in their branch of operation, which by their characteristics are similar to the other companies from the branch, point to the fact that it is expected for their price of shares to grow, and consequently, it is expected for the return on such shares to be higher in the future. However, of the companies listed on the Macedonian Stock Exchange, some companies are unique by their branch of operation, due to which we do not have what to compare them with; the only thing that we could compare is this indicator for the company throughout the years.

On the basis of the conducted analysis, the lowest indicator is that of Beton AD, especially in 2012, when it totals 0.08, wheras the highest indicator is in 2009 for Makstil and it totals 2.87, i.e. the lowest indicator is in the construction sector, and the highest one is in the industrial sector. There are cases when the P/B coefficient is high, the company has a high ROE, but the return on profit is low. Therefore, a distinction between "good companies" and "good investments" is made. ${ }^{8}$

The next indicator to value companies is the return on capital ${ }^{9}$. It is obtained in the following manner:

Return on capital $=\frac{\text { Net profit }}{\text { Capital }}$

It shows how much profit the company makes in relation to its capital and it is expressed in percentages, i.e. it measures in percentages the return on the capital employed. One should take into consideration in which companies the return on capital is higher or above the average due to the fact that these companies have small liabilities, as well as the potential to develop with small capital expenditures, which is a signal that such companies will accomplish significant return on the capital employed in the future as well. The link with the previous indicator can also be seen in the fact that the companies which have an overestimated share price growth have a low return on capital and a high total for the market - book price per share ratio indicator.

Table 7. Return on capital - ROE of companies which constitute the MBI 10 for the period 20082012

\footnotetext{
${ }^{8}$ Zvi Bodie, Alex Kane, Alan Marcus, Investments - 2010, p. 658

${ }^{9}$ Gerald White, referenced work p. 218, Steven Bragg, referenced work p. 382, Pamela Peterson, referenced work p. 121.
} 


\begin{tabular}{llllll}
\hline Alkaloid AD & $8.06 \%$ & $8.86 \%$ & $8.71 \%$ & $8.91 \%$ & $8.63 \%$ \\
Beton AD & $2.28 \%$ & $1.85 \%$ & $1.63 \%$ & $1.00 \%$ & $1.08 \%$ \\
GD Granit AD & $7.08 \%$ & $10.13 \%$ & $8.90 \%$ & $10.54 \%$ & $14.02 \%$ \\
$\begin{array}{l}\text { ZK Pelagonija } \\
\text { AD }\end{array}$ & $6.28 \%$ & $14.07 \%$ & $-2.62 \%$ & $-7.41 \%$ & $10.85 \%$ \\
$\begin{array}{l}\text { Komercijalna } \\
\text { banka AD }\end{array}$ & $5.86 \%$ & $11.40 \%$ & $17.89 \%$ & $15.46 \%$ & $22.03 \%$ \\
Makpetrol & $-1.80 \%$ & $-0.08 \%$ & $-5.97 \%$ & $-7.11 \%$ & $5.90 \%$ \\
$\begin{array}{l}\text { Makstil } \\
\text { Replek AD }\end{array}$ & $-0.96 \%$ & $-7.81 \%$ & $3.92 \%$ & $0.15 \%$ & $6.53 \%$ \\
$\begin{array}{l}\text { Stopanska Banka } \\
\text { AD Bitola } \\
\text { Toplifikacija AD }\end{array}$ & $-11.40 \%$ & $10.84 \%$ & $6.02 \%$ & $11.26 \%$ & $18.29 \%$ \\
\hline
\end{tabular}

Source: Financial reports for the companies from which the MBI 10 index is calculated for the period 2008-2012

The highest return on own capital is achieved by Komercijalna Banka AD - 5.86\% in 2012, which totals $22.03 \%$ in 2008, whereas the lowest return on own capital is achieved by Stopanska Banka AD Bitola in $2011,-40.58 \%$ (graph 20).

\section{Valuing of share capital on the basis of return made}

When valuing companies on the basis of the return made, the return on dividend indicator is most often applied, knowing that the investors who invest in securities expect a dividend to be paid to them in the form of expected return on the investment in those securities. However, it is important if and how much the company pays out a dividend, since although it may achieve a positive financial result, the companies often do not distribute a dividend, since the net profit is invested in more productive projects, as well as how much the dividend is, compared with the price per share on the market. ${ }^{10}$ This indicator is calculated using the following formula:

Return on dividend $=\frac{\text { Dividend per share }}{\text { Market price per share }}$

The indicator shows the current rate of return secured for the shareholders compared with the market price per share. Here, the market price of the shares is used as a criterion against which the return on investment is compared in order for the investor to decide whether to keep the share or to sell it since they are dissatisfied with the return. Having in mind that the return on dividend is expressed in percentages, these data can be compared between the companies and it can be observed which company actually pays out more dividend, and which less. Often, this indicator is a piece of information which is useful for the investors when reaching a business decision. However, the decision should not be solely

${ }^{10}$ Pamela Peterson, referenced work p. 122. 
based on this datum, but the other indicators which give us a clearer picture of the company should also be taken into consideration and a more profitable decision for investment should be reached.

Table 8. Return on dividend for companies listed on the Macedonian Stock Exchange for the period 2008-2012

\begin{tabular}{llllll}
\hline Alkaloid AD & $4.42 \%$ & $4.20 \%$ & $4.26 \%$ & $3.2 \%$ & $4.5 \%$ \\
Beton AD & $/$ & $/$ & $/$ & $/$ & $/$ \\
GD Granit AD & $2.55 \%$ & $2.6 \%$ & $1.89 \%$ & $3.39 \%$ & $3.09 \%$ \\
ZK Pelagonija AD & $/$ & $/$ & $/$ & $/$ & $10.51 \%$ \\
Komercijalna banka AD & $3.83 \%$ & $5.93 \%$ & $6.17 \%$ & $6.07 \%$ & $6.91 \%$ \\
Makpetrol & $/$ & $/$ & $/$ & $/$ & $3.12 \%$ \\
Makstil & $/$ & $/$ & $/$ & $/$ & $/$ \\
Replek AD & $10.49 \%$ & $8.5 \%$ & $8.04 \%$ & $6.91 \%$ & $12.37 \%$ \\
Stopanska Banka AD Bitola & $/$ & $/$ & $/$ & $4.93 \%$ & $8.70 \%$ \\
Toplifikacija AD & $2.83 \%$ & $/$ & $1.89 \%$ & $0.71 \%$ & $/$ \\
\hline
\end{tabular}

Source: Financial reports for the companies from which the MBI 10 index is calculated for the period 2008-2012

The highest return on dividend is achieved by the shareholders of Replek AD, especially in 2008 and it is $12.37 \%$, whereas the lowest return on dividend is achieved by Toplifikacija AD Skopje in 2009 and it totals $0.97 \%$.

On the basis of the presented content, the investors will be able to differentiate among the models of valuation. Nowadays, as it is known, the models mentioned in all reference books are functional as they are presented only in the frames of a perfect world. Taking into consideration the fact that such world does not exist and that today we are living in a real world, it goes without saying that all those models will produce different results if they are applied in different places. Certainly, the data used in the separate models will also in fact represent an estimate for future values. Through the explanation of the given valuation models, which, as it has been mentioned, can be models based on assets, models based on dividends, models based on revenue, as well as the free cash flows approach to valuation, we have seen that when applying them, we are faced with a large number of obstacles and difficulties. As the most common obstacles, one is faced with difficulties with predicting the final horizon, the volatile nature of cash flows, as well as the fact that the application of the models is influenced by the bookkeeping policies of the company and the discretionary policies of the management.

The valuation indicators should not be seen in an isolated manner and independently from the other indicators. That means that future investors should be careful when applying some indicators. As a result of that, each separate indicator should only be the starting base and should not be reviewed isolated 
from the other indicators, but the remaining indicators should also be taken into account as ways to evaluate the company, thus enabling investors to reach the right decision in terms of where, in which company, to invest their available assets and to expect the greatest return on the invested assets.

\section{Valuation of companies using the DCF method}

The company valuation method according to the amount of the discounted cash flow, i.e. the DCF method, is the most typical investment method used. Unlike the concept of return, the cash flow covers the cash net revenues which are created in the company, and which remain at the disposal of the investor. Just like in the case of the company valuation method according to the return, in this approach, too, the goal is to determine the value of the company's own capital. However, the difference is in the fact that it is determined according to a different effect - the cash flow, and not the return.

In the approach using the estimation of the company's own capital, the value of the company is obtained if the long-term debt of the company is subtracted from the current value of the cash flow.

The cash flow, as a basis for valuing the company, is formed of the following elements:

1. net earnings before taxes (so-called EBIT);

2. amortization;

3. return on net turnover capital (investments in turnover assets);

4. investments in fixed assets.

A scenario analysis is used in the projections. Three scenarios are prepared - an optimistic one, a pessimistic one and a most likely one.

In order to conduct a scenario analysis, one should study the relevant factors which determine the cash flow elements - the revenues and the expenditures. Each scenario assumes a complete analysis of the company environment, the demand and its performances in different hypothetical operation circumstances, the sensitivity to certain changes in the key variables. Each scenario is formed using a pile of hypotheses taken at the same time and together, each scenario represents a new hypothetical situation in which the company could be found. The imagined situations result from the analysis of different situations in which the company could be found in the future as a result of its available potential, as a result of the competition, as a result of the company's financial power etc. In that way, independent scenarios are developed. As a result of each scenario, an income sheet and a balance sheet are projected, as well as an overview of the cash flow, and then an overview of the discounted cash flow is formed. An estimated value of the company results from each scenario. We can decide on the value according to one of the scenarios, but the value can also be formed according to the weighted arithmetic mean of the three scenarios, where the weights would be the coefficients of probability which we could determine to be our position: The position results from the analysis of the strengths and weaknesses in each of the scenarios.

Using separate scenarios, in fact, the limits of the company value are set - the highest and the lowest. In the end, the sensitivity of the returned value is checked, as well as the influence of the change on the key variables - the length of the period of projection, the discount rate, the changes in the prices of the expenditures, etc. The idea about the value of the company is clarified with their examination.

The evaluation of the value of the company becomes an important piece of information for the management, for the shareholders and for all interested parties, potential and current ones. In the case of a company sale, the estimation of the buyer and the seller is argumented and the evaluation gives information so they could negotiate and reach a reasonable and fair price which would be acceptable for the transaction for both negotiators. In this part, the share capital of five companies listed on the Macedonian Stock Exchange is valued according to the method of discounted cash flows, including: Alkaloid AD, Replek AD, Komercijalna Banka AD, Granit AD and ZK Pelagonija.

Appendix 1 provides the models for determining the capital value of Alkaloid AD, Replek AD, Komercijalna Banka AD, Granit AD and ZK Pelagonija. Each scenario is formed using a pile of hypotheses taken at the same time and together and each scenario represents a new hypothetical situation 
in which the company could be found. The imagined situations result from the analysis of different situations in which the company could be found in the future as a result of its available potential, as a result of the competition, the financial power of the company, etc. Since all companies operate under the same circumstances and the same time period is in question, the hypotheses are the same for all three scenarios. One should have in mind that the valued companies are not companies from the same branch of operation and of the same size.

In the most likely scenario, the hypotheses are as follows: growth of the return for $2 \%$, consequently growth of the expenditures for $1.5 \%$. The discount rate in the concrete case shall be $9 \%$; since we do not have the $\beta$ coefficient as a factor for calculating the WACC, the discount factor has been obtained as an interest rate of the long-term loans which totals $7 \%$ with additional $2 \%$ added to that rate as occupation risk (Appendix 1). On the basis of the above-mentioned hypotheses about the most likely scenario, the value of the capital of Alkaloid AD, Replek AD, Komercijalna Banka AD, Granit AD and ZK Pelagonija expressed in EUR with an average Euro rate of $1 €=61.3$ MKD is provided in table 9. In the optimistic scenario, the hypotheses are as follows: growth of the revenues from sales for 5\% and growth of expenditures for $2 \%$; the remaining indicators remain the same just like in the most likely scenario, and the value of the capital of the company is provided in table 9.

The pessimistic scenario is based on hypotheses in less favourable conditions, i.e. growth of revenues for $1 \%$, where the growth of expenditures is $1.5 \%$, and with such hypotheses the capital value is decreased, and the concrete case is shown in table 9 .

Table 9. Value of company capital calculated according to the DCF method

\begin{tabular}{llll}
\hline Komercijalna banka AD & $135,914,651$ & $155,461,445$ & $114,889,062$ \\
GD Granit & $172,209,791$ & $175,332,381$ & $41,577,175$ \\
Replek AD & $43,044,816$ & $46,220,522$ & $34,947,307$ \\
ZK Pelagonija & $38,945,429$ & $59,625,517$ & $28,116,651$ \\
Alkaloid AD & $33,711,701$ & $54,030,046$ & $32,781,036$ \\
\hline
\end{tabular}

Source: Own calculations based on formulated hypotheses

On the basis of this capital valuation model, too, the capital of Komercijalna Banka AD is valued higher in table 3.23., after which comes the construction company Granit, Replek AD, etc.

\section{Conclusion}

In order to value the ordinary shares and at the same time the share capital, numerous valuation models were used, models of discounted free cash flows, and relative valuation models

Regardless of which valuation models are applied, they have common factors: an influential factor is the share profit rate, and both models are under the influence of the increase rate of variables, regardless whether it is the dividend, the profit, the cash income or the sales.

The advantage of the relative models is in the fact that information about how the market presently values shares on different levels, in the frames of the industry, among the alternative industries and at the aggregate market, is provided. The most applicable models are: ${ }^{11}$ price to book value ratio, price to cash flow ratio, price to sales ratio, or some other market indicator which has been created.

These models are applicable if two basic requirements are met:

${ }^{11}$ Ibid. p.623 
- If companies or similar industries are compared, (it is preferable that the companies be of the same size, industry and to be at the same level of risk),

- The aggregate market not to have extreme values.

In this paper, the relative models are used for the evaluation of the shares that are part of the MBI $10^{12}$ index. This evaluation has been made from the aspect of:

- revenues made;

- results achieved;

- cash flow;

- available capital; and

- return made,

i.e. relative indicators and coefficients are used in order to see the valuation of the capital and the shares from the aspect of the achieved financial result, the market capitalization, and the relative indicators in order to get a real value of the shares taking into consideration all the strengths and weeknesses of the data received.

\section{References}

1) Bodie Z.,Kane A., Markus A.: "Investments”, Seventh ed., Mc Graw Hill, 2008.

2) Gerald I. White, Ashwinpaul C. Sondhi and Dov Fried " The analysis and use of Financial Statement" 1998 by John Wiley\& Sons. Inc.

3) Steven Bragg: Financial Analysis A Controller's Guide, John Wiley \& Sons,New Jersey, 2007.

4) Ray Ball S. P. Kothari “Financial Statement Analyses” by Mc Craw Hill, Inc, New Jork 1994.

5) Pamela Peterson, Frank Fabozzi: Analysis of Financial Statements, John Wiley \& Sons, Inc., 2006.

6) Revsine i dr.: Financial Reporting \& Analysis, McGraw-Hill, Irwin, 2009.

7) Hoyle, Schaefer, Doupnik: Advanced Accounting, McGraw-Hill, Boston, 2009.

8) B. Lorris. "A Financial Early Warning System for Over-the-Counter Broker Dealers.” Journal of Finance September 1976.

9) Stephen H Penmen "Return to Fundamentals"1991

${ }^{12}$ Translator's comment: The MBI 10 index is the Macedonian Stock Exchange blue chip index 